\title{
Community structure of the ichthyofauna associated with seagrass beds (Halodule wrightii) in Formoso River estuary - Pernambuco, Brazil
}

\author{
PEDRO H.C. PEREIRA, BEATRICE P. FERREIRA and SÉRGIO M. REZENDE \\ Departamento de Oceanografia, Universidade Federal de Pernambuco, UFPE, Centro de Tecnologia e Geociências (CTG) \\ Av. Arquitetura, s/n, Cidade Universitária, 50670-901 Recife, PE, Brasil \\ Manuscript received on August 21, 2009; accepted for publication on November 22, 2009
}

\begin{abstract}
Seagrass beds are used by juvenile fishes in different ways, generally as nursery sites, shelter from predators, reducing competition and increasing availability of food resources, thus establishing a relationship of connectivity with other ecosystems. In the present study, the community structure of the ichthyofauna associated with seagrass beds on the Formoso River (Pernambuco - Brazil) was evaluated during the winter of 2008. Twenty-seven manual trawls (15 daytime and 12 nighttime) were performed, and a total of 358 fishes belonging to 18 families, 21 genus and 25 species were collected. The Catch Per Unit Effort (CPUE) by trawling average was 13.5 and 4.95 individuals per species per trawl. The most abundant families were Scaridae $(\mathrm{n}=111)$, Tetraodontidae $(\mathrm{n}=63)$, Lutjanidae $(\mathrm{n}=56)$, Mullidae $(\mathrm{n}=$ 39 ) and Engraulidae $(n=19)$. Ecological indices for dial changes were always higher for the night period, confirming that such areas are used more frequently during this period. The need for measures to conserve these areas is emphasized, by its importance and vulnerability to human impacts.
\end{abstract}

Key words: connectivity, seagrass beds, reef fishes, diversity.

\section{INTRODUCTION}

The use of seagrass beds by several species of fishes has received considerable attention because of the connection between, the mangroves and coral reefs (Pollard 1984, Parrish 1989, Beck et al. 2001). However, the importance of these ecosystems for reefs/estuarines fishes has not been adequately quantified. It is necessary to know the real function of seagrass beds as refuge areas from predators, areas of decreased competition and increased availability of food resources (Blaber and Blaber 1980, Laegdsgaard and Johnson 2001, Adams and Ebersole 2002).

The protection and management of seagrass beds environments are essential for the survival of many marine species connected to coral reefs, sand plains and estuaries, forming a mosaic of shallow water environ-

Correspondence to: Pedro Henrique Cipresso Pereira

E-mail: pedrohcp2@yahoo.com.br ments (Beck et al. 2001). Important ecological connections among these ecosystems include energy flow and use of a combination of habitats throughout the life cycle of animals, determined by ontogenetic migration (Meyer et al. 1983, Parrish 1989).

Non-reef habitats located near the reef systems act as buffer areas. They keep the recruitment levels even during the periods in which they are low, and act as corridors ("stepping stones") where fishes move freely while keeping the connectivity among the habits of juvenile, subadult and adults (Laegdsgaard and Johnson 1995, Gillanders et al. 2003, Mumby et al. 2003).

Many families of reef fishes with ecological and economic importance (e.g. Haemulidae, Lutjanidae, Mullidae and Scaridae) migrate among the areas that maintain connectivity among coastal ecosystems (Beck et al. 2001). Large aggregations of juveniles of Haemulidae, for example, are found close to areas of man- 
groves, seagrass and coral reefs and, thus, perform ontogenetic migrations among these areas, which involve changes in diet and behavior (Lindeman et al. 2000, Cocheret de la Morinière et al. 2003).

Several studies have been performed worldwide describing the community of the ichthyofauna in seagrass areas (e.g. Weinstein and Heck 1979, Verweij et al. 2006, Allen et al. 2007, Lugendo et al. 2007, Nakamura and Tsuchiya 2008). In Brazil, few studies have been conducted (Schwamborn 2004, Rezende 2008), and there is a clear need for extending this line of studies to improve the understanding of ecological relationships in these ecosystems.

This study aims to evaluate the community structure of the ichthyofauna associated with seagrass beds of Formoso River estuary during the winter months (June to August) in Tamandaré municipality, Pernambuco State. Species composition, abundance, diversity, size/weight data and trophic guilds were used to describe the fish community.

\section{MATERIALS AND METHODS}

\section{STUDY AREA}

The study area is included in the limits of two multipleuse protected areas: "APA de Guadalupe" and "APA Costa dos Corais".

The Environmental Protection Area (EPA) de Guadalupe is spread to continental and marine areas and covers four municipalities: Sirinhaém, Formoso River, Tamandaré and Barreiros. The Environmental Protection Area (APA) Costa dos Corais, extended to over $135 \mathrm{~km}$ of coastline from Tamandaré, southern state of Pernambuco, to Maceió, state of Alagoas, and is the first unit of the federal conservation that includes coastal reefs. It is also the largest marine conservation unit in Brazil (Ferreira and Cava 2001).

The study was conducted in the municipality of Tamandaré (Fig. 1), which is characterized by reef formations parallel to the coast. It has a tropical climate with a dry season from October to March, with temperatures around $30^{\circ} \mathrm{C}$ and a rainy season between April and September, with temperatures around $26^{\circ} \mathrm{C}$ (Maida and Ferreira 1997). Samples were collected at Carneiros beach $\left(8^{\circ} 41^{\prime} 33^{\prime \prime} \mathrm{S}\right.$ and $\left.35^{\circ} 05^{\prime} 14^{\prime \prime} \mathrm{W}\right)$, which has a very diverse range of ecosystems (mangroves, sand banks, seagrass beds and coral reefs).

The seagrass beds found in the area are mainly composed by Halodule wrightii, which are positioned parallel to the coastline and are spread over a small part of Carneiros beach. They are usually inserted among plains of sand, with an average depth between 0.5 and $2.0 \mathrm{~m}$ and making patches of short extensions. Channels are reported between the sand plans and the seagrass meadows, which can be used for the migration of species in general (personal observation).

\section{SAMPLING}

Samples were collected monthly during day and nightime in the seagrass beds in the winter months (June to August) using a manually operated bottom trawl for capturing juvenile fishes and settlers. It consisted of a PVC frame $1,5 \times 1,0 \mathrm{~m}$, with a $5 \mathrm{~mm}$ mesh. Trawling was performed parallel to the coast-line and at random location for three minutes each. No nocturnal sampling was held during the month of June due to logistical conditions.

After the completion of trawls, all the collected material was sorted. Fishes were separated and placed in a plastic tray with sea water while the remaining material (invertebrates, algae and sediment) were promptly returned to the ocean. The collected fishes were taken to the laboratory of CEPENE/IBAMA, and individuals were weighed, measured and included in classes of length, then fixed in a solution of $10 \%$ formalin and preserved in alcohol $70^{\circ}$ GL. The Catch Per Unit Effort (CPUE) was calculated for each trawl and was (Ind. $/$ Trawl) $=$ Number of individuals per trawl.

At all the sampling points the temperature $\left({ }^{\circ} \mathrm{C}\right)$ and surface water salinity (PSU) were measured.

\section{DATA ANALYSIS}

Indices were calculated to compare the ichthyofauna between day periods and months of samples. The diversity index of Shannon-Wiener ( $\left.\mathrm{H}^{\prime}\right)$, species richness of Margalef (D) and equitability of Pielou (J') were calculated using the software Species Diversity Richness, version 1.2.

To compare the number of species that occurred during the day and night time, a G test (Zar 1999) was used; to compare the differences among values of eco- 

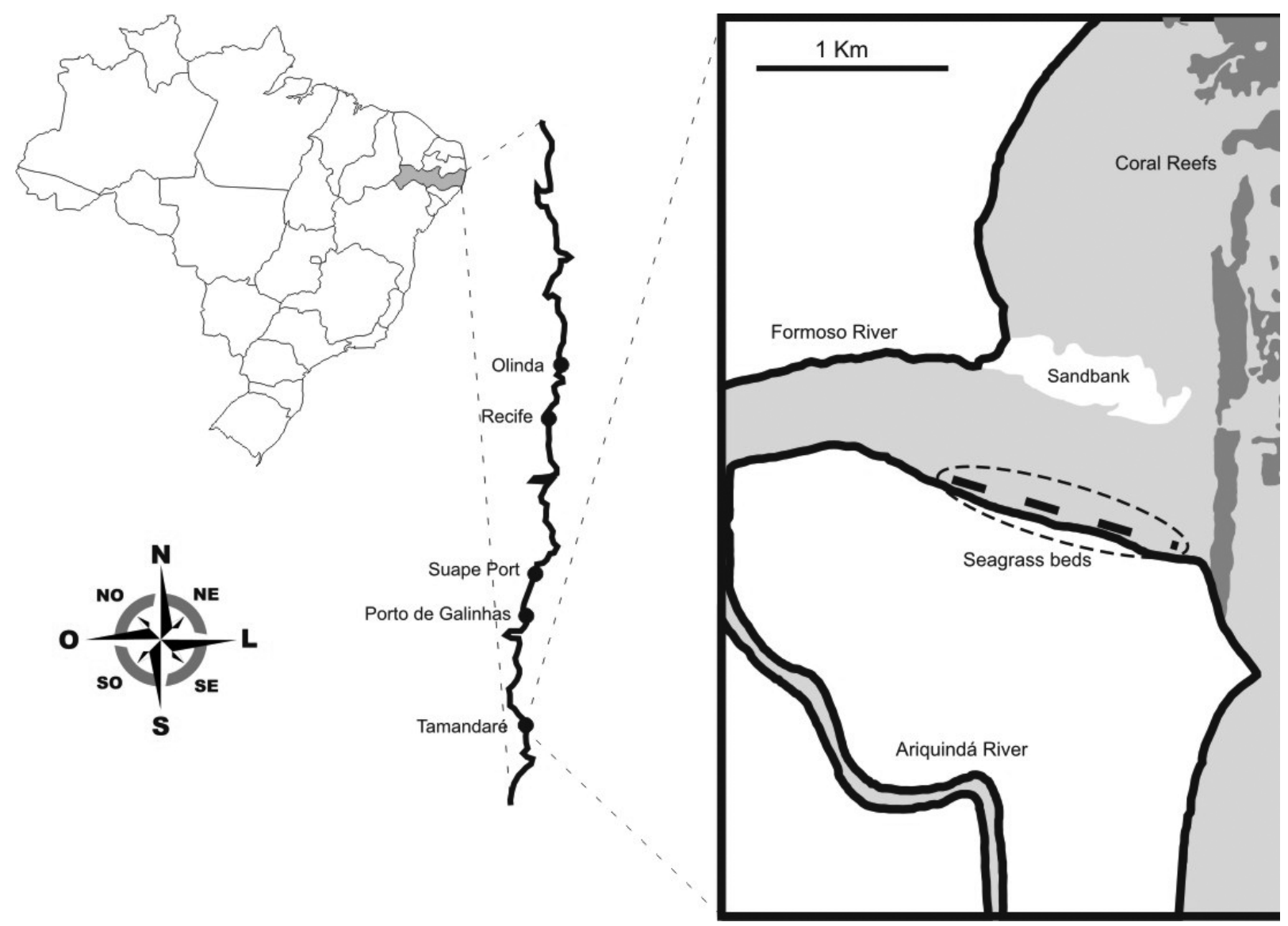

Fig. 1 - Map of the study area with the associated ecosystems (sand banks, seagrass beds and coral reefs).

logical indices, the Kruskal-Wallis test (Zar 1999) was used, both available on BioEstat 3.1 software (Ayres et al. 2003). Normality and homogeneity of variances were tested using the software StatView (Roth et al. 1995).

The collected species were separated according to the feeding habits and, then, grouped into six trophic guilds (Ferreira et al. 2004): OMN: Omnivores, CAR: Carnivores, MIF: Mobile invertebrate feeders, PIS: Piscivores, SIF: Sessile invertebrate feeders, and HER: Herbivores.

\section{RESULTS}

Twenty-seven manual trawls (15 daytime and 12 nocturnal) were performed during winter months (June to August 2008). A total of 358 individuals were collected, weighed, measured and identified to the species level, corresponding to 18 families, 21 genera and 25 species. The average catch was of 13.5 individuals per trawl, with a maximum of 35 individuals and a minimum of three, while the average species richness was of 4.95 species per trawl, with a maximum of 10 species and a minimum of one (Table I).

Environmental conditions in winter were of lower temperatures and higher pluviosity in the region. The minimum temperature recorded was $24.5^{\circ} \mathrm{C}$ and maximum of $26.5^{\circ} \mathrm{C}$, whereas the minimum recorded salinity was 32.1 PSU and the maximum was 38.3 PSU.

Individuals of Sparisoma axillare (Scaridae) $(\mathrm{n}=$ 104), Sphoeroides spengleri (Tetraodontidae) $(\mathrm{n}=46)$ and Lutjanus synagris (Lutjanidae) $(\mathrm{n}=36)$ were the most frequent, occurring respectively in $81.4 \%, 77.7 \%$ and $59.2 \%$ of the samples. Subsequently, Scorpaena plumieri (Scorpaenidae) $(\mathrm{n}=17)$ and Pseudupeneus maculatus (Mullidae) $(\mathrm{n}=39)$ were the two most frequent with $33.3 \%$ frequency of occurrence. The other collected species, about $48 \%(n=13)$ were recorded at just $10 \%$ of samples, which were: Hemiramphus brasiliensis, 
TABLE I

Summary of the number of samples, average and number of individuals and variations in environmental conditions during the studied months. Ind./Trawl = Average number of individuals per trawl. Spe. $/$ Trawl $=$ Average total number of species per trawl.

\begin{tabular}{c|c|c|c|c|c|c|c}
\hline Months & $\begin{array}{c}\text { Temp. } \\
\left({ }^{\circ} \mathrm{C}\right)\end{array}$ & $\begin{array}{c}\text { Salin. } \\
(\mathrm{psu})\end{array}$ & Tide & $\begin{array}{c}\text { N. } \\
\text { Ind. }\end{array}$ & N. Trawl. & $\begin{array}{c}\text { Ind./ } \\
\text { Trawl. }\end{array}$ & $\begin{array}{c}\text { Spe./ } \\
\text { Trawl. }\end{array}$ \\
\hline June -2008 & 25.2 & 32.1 & Spring & 92 & 5 - Daytime & 18.40 & 4.80 \\
\hline July -2008 & 26.5 & 36.4 & Neap & 44 & 6 - Daytime & 7.33 & 3.83 \\
\hline July - 2008 & 24.5 & 35.2 & Spring & 107 & 6 - Nocturnal & 17.83 & 6.16 \\
\hline August -2008 & 24.6 & 37.0 & Spring & 52 & 6 - Nocturnal & 8.66 & 5.10 \\
\hline August -2008 & 25.3 & 38.3 & Spring & 63 & 4 - Daytime & 15.75 & 5.00 \\
\hline Total & - & - & - & 358 & 27 & 13.5 & 4.95 \\
\hline
\end{tabular}

Rypticus saponaceus, Mycteroperca bonaci, Archosargus rhomboidalis, Mulloidichthys martinicus, Bodianus rufus, Doratonotus megalepis, Sparisoma frondosum, Malacoctenus delalandii, Barbulifer ceuthoecus, Acanthurus chirurgus, Stephanolepis hispidus and Sphoeroides greeley (Table II).

Among the recorded families, five were the most representative ones and comprised $80.4 \%$ of total individuals: Scaridae $(\mathrm{n}=111)$, which corresponds to $31.0 \%$ of all individuals, Tetraodontidae $(\mathrm{n}=63 ; 17.5 \%)$, Lutjanidae $(n=56 ; 15.6 \%)$, Mullidae $(n=40 ; 10.8 \%)$ and Engraulidae ( $\mathrm{n}=19 ; 5.3 \%)$.

The analysis of abundance by CPUE (Ind./Trawl), considering the more representative five families, indicated the family Scaridae as the most abundant (average of 4.11 Ind./Trawl) (Fig. 2).

\section{Diel VARIATION IN THE ABUNDANCE}

AND COMPOSITION OF THE ICHTHYOFAUNA

A total of five species were collected only in daytime samples: Bodianus rufus, Dactylopterus volitans, Doratonotus megalepis, Mycteroperca bonaci and Rypticus saponaceus which represent $18.5 \%$ of total collected taxa. Besides, these eight species were collected only during nighttime: Anchoa sp., Barbulifer ceuthoecus, Eucinostomus lefroyi, Hemiramphus brasiliensis, Mulloidichthys martinicus, Sparisoma frondosum, Sphoeroides greeleyi and Stephanolepis hispidus, which represents $29.6 \%$ of the total collected, thus, showing the highest species richness at night. Fourteen taxa were collected during the day and at night, representing $51.8 \%$ of the total.
A significant difference among the species collected during the daytime and at night was found $(G=130.51$, $\mathrm{df}=24, \mathrm{p}<0.01$ ), showing the use of the area by different species of the community at different periods of the day.

\section{Length AND Weight Composition}

The lowest total length (TL) observed was $1.0 \mathrm{~cm}$ for a Sphoeroides testudineus specimen, and the largest collected individual was a specimen of Hemiramphus brasiliensis with $20.0 \mathrm{~cm}$ of total length. The species that showed the larger range of length was Scorpaena plumieri - average of $14.2 \mathrm{~cm}$, ranging from 4.0 to $18.2 \mathrm{~cm}$, and the smaller was Sphoeroides greeleyi - average of $0.3 \mathrm{~cm}$, ranging from 1.5 to $1.8 \mathrm{~cm}$ (Table III).

Regarding weight patterns, the highest value was recorded for the species Scorpaena plumieri $-155.10 \mathrm{~g}$, and the lowest $(0.10 \mathrm{~g})$ for several species: Syngnathus folletti, Lutjanus synagris, Sparisoma axillare, Ctenogobius saepepallens, and Sphoeroides spengleri. The species that showed the greater weight range was Scorpaena plumieri - average of $153.30 \mathrm{~g}$, ranging from 1.80 to 155.10 , and the smaller was Syngnathus folletti $-0.10 \mathrm{~g}$, ranging from 0.10 to $0.20 \mathrm{~g}$ (Table III).

For most of species $(72.0 \% ; \mathrm{n}=18)$, the average $\mathrm{TL}$ is lower than the $10 \%$ of maximum total length found in the literature. Thus, individuals can be considered recruits or juveniles.

The five most representative families (Scaridae, Tetraodontidae, Lutjanidae, Mullidae and Engraulidae), and all individuals were grouped in size classes $(\mathrm{TL} \mathrm{cm})$ and are presented on Figure 3. The family Scaridae ( $n=$ 111) was the most abundant in the meadow samples, and 
TABLE II

Checklist of the collected species. $N=$ Absolute number of individuals F.O (\%) = Frequency of occurrence rates of total trawls; CPUE (Ind./Trawl) $=$ Number of individuals per trawl; Trophic. * = Trophic categories.

\begin{tabular}{|c|c|c|c|c|c|}
\hline Família* & Taxas* & $\mathrm{N}$. & F.O (\%) & CPUE & Trophic.* \\
\hline Engraulidae & Anchoa sp. & 19 & 22.2 & 0.70 & - \\
\hline Hemiramphidae & Hemiramphus brasiliensis (Linnaeus, 1758) & 1 & 3.7 & 0.03 & $\mathrm{OMN}$ \\
\hline Syngnathidae & Syngnathus folletti (Herald, 1942) & 5 & 11.1 & 0.18 & CAR \\
\hline Dactylopteridae & Dactylopterus volitans (Linnaeus, 1758) & 3 & 11.1 & 0.11 & MIF \\
\hline Scorpaenidae & Scorpaena plumieri (Bloch, 1789) & 17 & 33.3 & 0.62 & CAR \\
\hline Serranidae & Rypticus saponaceus (Bloch and Schneider, 1801) & 1 & 3.7 & 0.03 & MIF \\
\hline Epinephelidae & Mycteroperca bonaci (Poey, 1860) & 1 & 3.7 & 0.03 & PIS \\
\hline \multirow[t]{3}{*}{ Lutjanidae } & Lutjanus synagris (Linnaeus, 1758) & 36 & 59.2 & 1.33 & CAR \\
\hline & Lutjanus analis (Cuvier, 1828) & 7 & 11.1 & 0.25 & CAR \\
\hline & Lutjanus sp. & 13 & 37.0 & 0.48 & - \\
\hline Gerreidae & Eucinostomus lefroyi (Goode, 1874) & 10 & 11.1 & 0.37 & SIF \\
\hline Sparidae & Archosargus rhomboidalis (Linnaeus, 1758) & 2 & 7.4 & 0.07 & HER \\
\hline \multirow[t]{2}{*}{ Mullidae } & Mulloidichthys martinicus (Cuvier, 1829) & 1 & 3.7 & 0.03 & SIF \\
\hline & Pseudupeneus maculatus (Bloch, 1793) & 39 & 33.3 & 1.44 & SIF \\
\hline \multirow[t]{2}{*}{ Labridae } & Bodianus rufus (Linnaeus, 1758) & 1 & 3.7 & 0.03 & PIV \\
\hline & Doratonotus megalepis (Günther, 1862) & 1 & 3.7 & 0.03 & CAR \\
\hline \multirow[t]{3}{*}{ Scaridae } & Sparisoma axillare (Steindachner, 1878) & 104 & 81.4 & 3.85 & HER \\
\hline & Sparisoma amplum (Bonnaterre, 1788) & 6 & 14.8 & 0.22 & HER \\
\hline & Sparisoma frondosum (Ranzani, 1841) & 1 & 3.7 & 0.03 & HER \\
\hline Labrisomidae & Malacoctenus delalandii (Valenciennes, 1836) & 2 & 7.4 & 0.07 & MIF \\
\hline \multirow[t]{2}{*}{ Gobiidae } & Barbulifer ceuthoecus (Jordan and Gilbert, 1884) & 1 & 3.7 & 0.07 & MIF \\
\hline & Ctenogobius saepepallens (Gilbert and Randall, 1968) & 15 & 25.9 & 0.55 & MIF \\
\hline Acanthuridae & Acanthurus chirurgus (Bloch, 1787) & 4 & 7.4 & 0.14 & HER \\
\hline Monacanthidae & Stephanolepis hispidus (Linnaeus, 1766) & 1 & 3.7 & 0.03 & $\mathrm{OMN}$ \\
\hline \multirow[t]{3}{*}{ Tetraodontidae } & Sphoeroides spengleri (Bloch, 1785) & 46 & 77.7 & 1.70 & MIF \\
\hline & Sphoeroides testudineus (Linnaeus, 1758) & 15 & 25.9 & 0.55 & MIF \\
\hline & Sphoeroides greeleyi (Gilbert, 1900) & 2 & 7.4 & 0.07 & MIF \\
\hline
\end{tabular}

*Phylogenetic classification by (Nelson 2006). Trophic Organization by (Ferreira et al. 2004). OMN: Omnivores, CAR: Carnivores, MIF: Mobile invertebrate feeders, PIS: Piscivores, SIF: Sessile invertebrate feeders, HER: Herbivores.

was represented by three species: Sparisoma axillare (n =104), Sparisoma amplum $(\mathrm{n}=6)$ and Sparisoma fron$\operatorname{dosum}(\mathrm{n}=1)$, maximum and minimum TL of $9.0 \mathrm{~cm}$ and $1.5 \mathrm{~cm}$, respectively, with a mean size of $3.69 \mathrm{~cm}$.

\section{DIVERSITY, RICHNESS AND EQUITABILITY OF THE ICHTHYOFAUNA}

For the total fish community, the ecological indices values were: Shannon-Wiener diversity $\left(\mathrm{H}^{\prime}=2.66\right.$, standard deviation $=0.0042)$, Richness of Margalef $(\mathrm{D}=4.15)$ and Pielou equitability $\left(\mathrm{J}^{\prime}=0705\right)$. The obtained values per month and per period (daytime and nighttime) are given in Figure 4.

There was no significant differences among the analyzed months (Fig. 4A) $(\mathrm{H}=0462, \mathrm{df}=2, \mathrm{p}>0.05)$, indicating a small fluctuation in the community over the winter months.

Concerning the analysis of diel shifts, higher values were found for the night period, confirming that use of such areas by the ichthyofauna is more intense during 


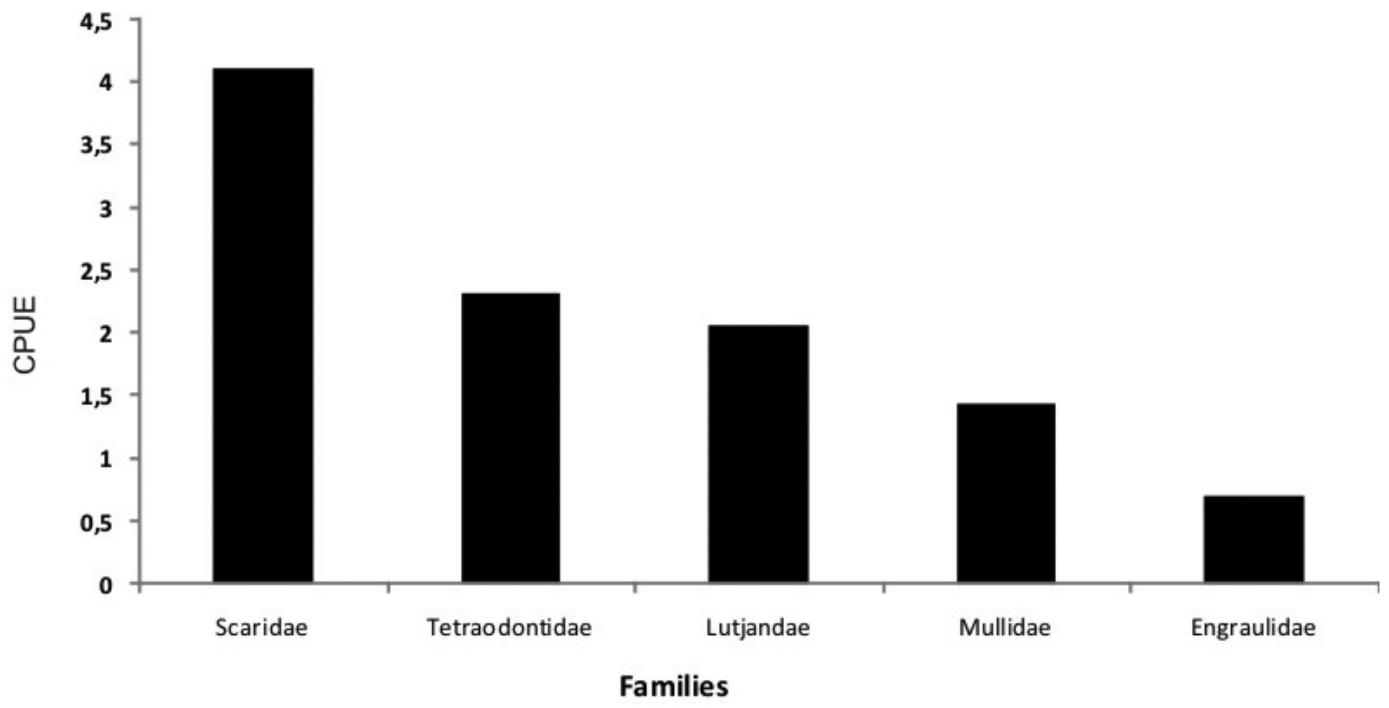

Fig. 2 - Abundance CPUE (Ind./Trawl) of the most representative families collected during the winter on Carneiros beach, Tamandaré - PE.

this period, with daytime values of $\left(\mathrm{H}^{\prime}=1.86-\right.$ standard deviation $=0.0080),(\mathrm{D}=3.25)$ and $\left(\mathrm{J}^{\prime}=0.57\right)$, and nightime values of $\left(\mathrm{H}^{\prime}=2,33-\right.$ standard deviation $=$ $0.0078),(\mathrm{D}=3.84)$ and $\left(\mathrm{J}^{\prime}=0.72\right)$, (Fig. 4B).

\section{TROPHIC GUILDS}

Most of the collected species was classified as Mobile invertebrate feeders (36\%), followed by Carnivores (20\%) and Herbivores (20\%) (Fig. 5). Concerning the number of individuals for each trophic guild, herbivores were the most representative, with 117 individuals (36.33\%), followed by mobile invertebrate feeders, with 86 individuals $(26.76 \%)$, and carnivores with 66 individuals (20.59\%).

\section{DISCUSSION}

It is well known that the density of fishes associated with marine seagrass beds is directly related to leaf area of plant and structural complexity of the dominant algae (Jernakoff et al. 1996). The studied area is characterized by the predominance of the species Halodule wrightii, which is among the species of smaller leaf surface (Jernakoff et al. 1996).

Ichthyofauna studies in mangroves areas and seagrass beds showed that such sites have a relatively high number of species (Nagelkerken et al. 2000, Unsworth et al. 2007). However, a small number of species dominates the structure of the local community in terms of numerical abundance (Quinn 1980, Lugendo et al. 2007). In Madagascar, for example, five species were found representing this total (Laroche et al. 1997); in Australia, only three species (Kwak and Klumpp 2004) were found and in an estuary in the Northeast Brazil (Barletta et al. 2005), six species. In the present study, by analyzing just the winter months (June, July and $\mathrm{Au}-$ gust), this trend was confirmed, with eight species representing $81 \%$ of the whole community sampled.

The understanding of changes in the abundance and diversity of fish fauna in seagrass meadows during day/night periods is a key factor to understand the community dynamics (Bell and Harmelin-Vivien 1982, Cocheret de la Morinière et al. 2003, Lugendo et al. 2007). Many previous studies concluded that both the number and density of species were higher at night (Baelde 1990, Nagelkerken et al. 2000, Letourneur et al. 2001, Jelbart et al. 2007), mainly due to the fact that many species use the reef environment as a structural refuge during the day, but depending on the seagrass beds and other areas of connectivity to feed at night and dusk. This same pattern was confirmed in this study with values always higher at night.

Studies of faunal communities in seagrass meadows on the coast of Pernambuco were conducted by Ramos (1973), M.S. Alves (unpublished data), G.F.S. Viana (unpublished data), Alves (2000), Schwamborn (2004) and Rezende (2008), four of them emphasizing fish commu- 

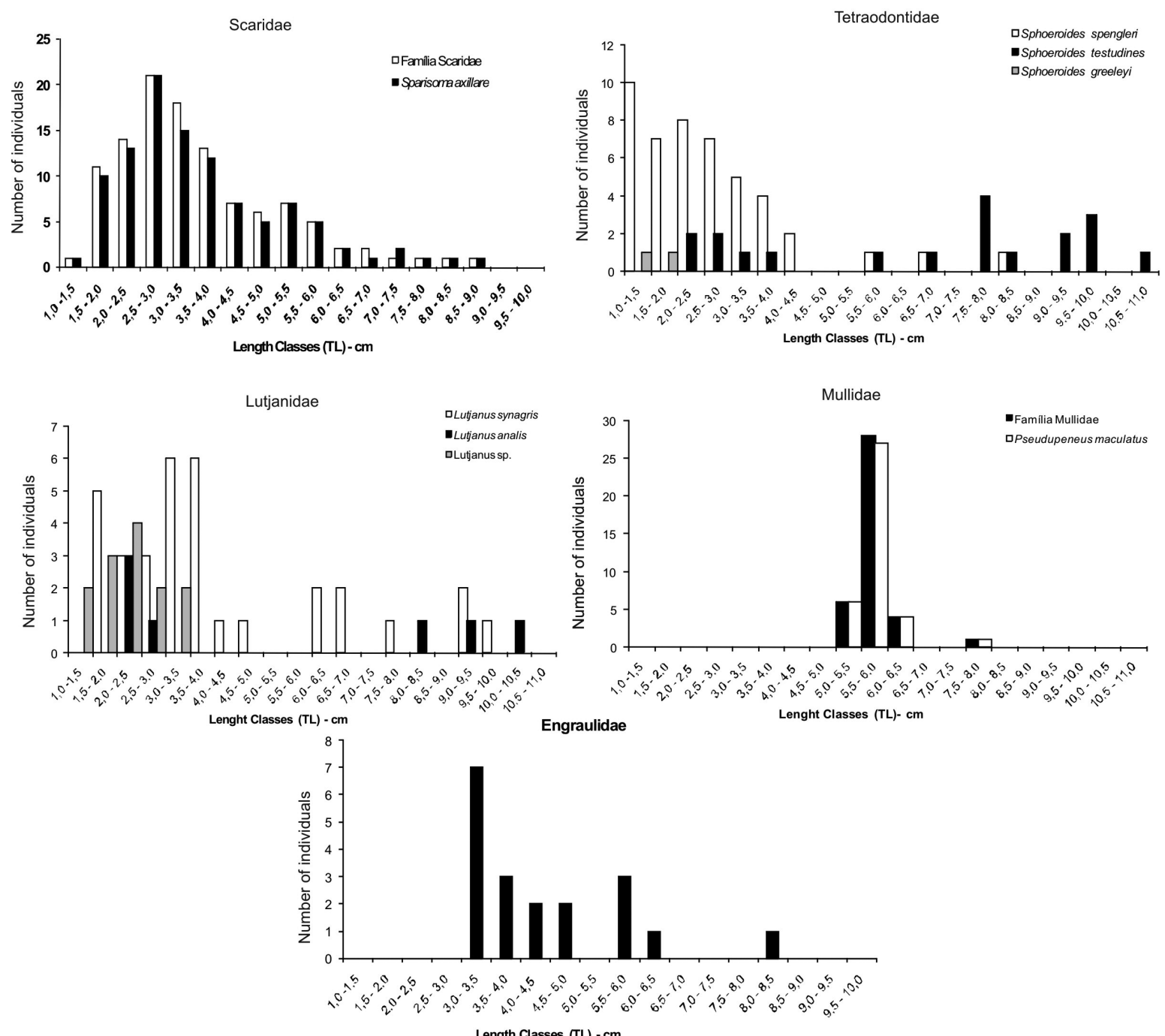

Fig. 3 - Abundance CPUE (Ind./Trawl) of the most representative families collected during the winter on Carneiros beach, Tamandaré - PE.

A

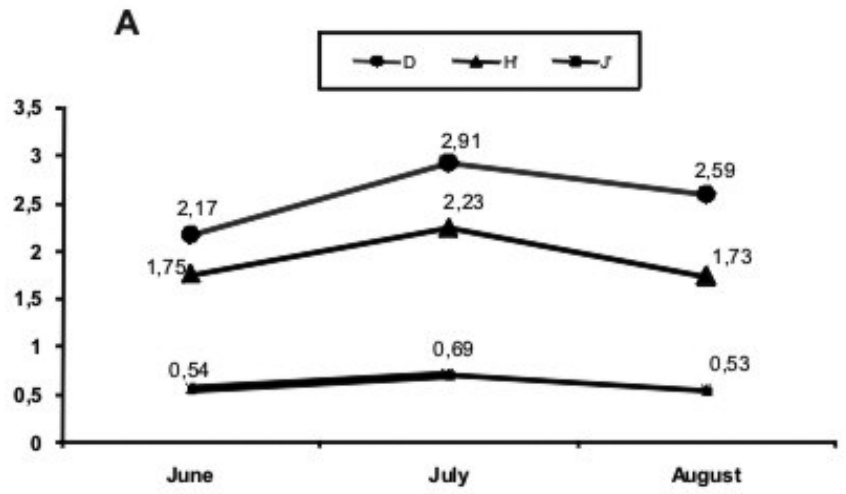

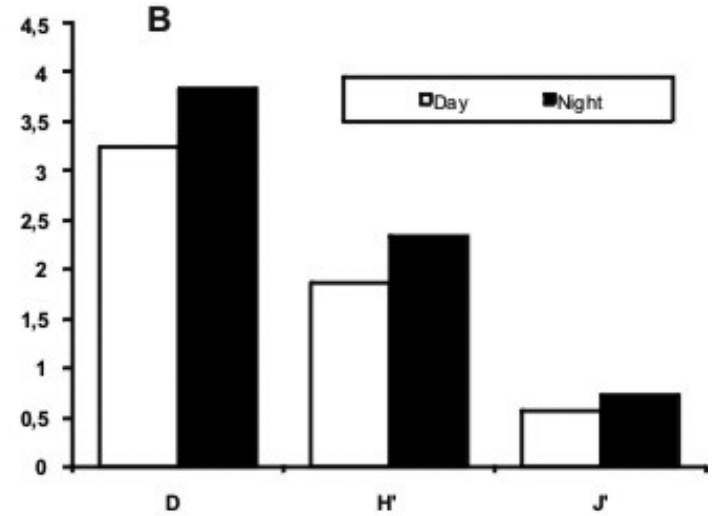

Fig. 4 - Diversity indices: Shannon-Wiener (H'), Richness of Margalef (D) and Equitability of Pielou (J') by month (A) and for different periods of the day (B) to the sampled ichthyofauna during the study. 
TABLE III

Structure of ichthyofauna depending on length and weight, with the average total length (TL) and weight, on the amplitude with maximum and minimum values. TL $\max =$ Maximum size recorded in literature (cm). Humann and Deloach 2002, Fishbase 2009.

\begin{tabular}{|c|c|c|c|c|c|c|}
\hline Species & N. & $\begin{array}{l}\text { Average } \\
\text { TL (cm) }\end{array}$ & $\begin{array}{l}\text { Variation } \\
\text { TL (cm) }\end{array}$ & $\begin{array}{c}\text { TL Max - cm } \\
\text { (literature) }\end{array}$ & $\begin{array}{c}\text { Weight } \\
\text { average }(\mathrm{g})\end{array}$ & $\begin{array}{c}\text { Weight } \\
\text { variation }(\mathrm{g})\end{array}$ \\
\hline Anchoa sp. & 19 & 4.57 & $3.2-8.5$ & - & 1.47 & $0.1-9.3$ \\
\hline Hemiramphus brasiliensis & 1 & 20.0 & - & 55.0 & 20.80 & - \\
\hline Syngnathus folletti & 5 & 5.58 & $3.5-7.2$ & 25.0 & 0.12 & $0.1-0.2$ \\
\hline Dactylopterus volitans & 3 & 9.63 & $9.2-10.1$ & 50.0 & 15.4 & $14.5-17.1$ \\
\hline Scorpaena plumieri & 17 & 6.30 & $4.0-18.2$ & 51.0 & 14.1 & $1.8-155.1$ \\
\hline Rypticus saponaceus & 1 & 3.01 & - & 35.0 & 0.31 & - \\
\hline Mycteroperca bonaci & 1 & 4.03 & - & 120.0 & 0.80 & - \\
\hline Lutjanus synagris & 36 & 4.80 & $1.9-12.8$ & 60.0 & 4.37 & $0.1-35.2$ \\
\hline Lutjanus analis & 7 & 5.80 & $1.6-15.0$ & 85.0 & 10.5 & $0.1-51.2$ \\
\hline Lutjanus sp. & 13 & 2.25 & $1.0-3.2$ & - & 0.34 & $0.1-0.7$ \\
\hline Eucinostomus lefroyi & 10 & 2.45 & $1.7-3.5$ & 25.0 & 0.27 & $0.1-0.7$ \\
\hline Archosargus rhomboidalis & 2 & 9.41 & $4.1-14.7$ & 33.0 & 31.31 & $1.1-61.5$ \\
\hline Mulloidichthys martinicus & 1 & 3.12 & - & 39.4 & 0.22 & - \\
\hline Pseudupeneus maculatus & 39 & 5.89 & $5.2-8.0$ & 35.0 & 2.24 & $1.3-7.3$ \\
\hline Bodianus rufus & 1 & 3.32 & - & 40.0 & 0.52 & - \\
\hline Doratonotus megalepis & 1 & 2.11 & - & 9.4 & 0.53 & - \\
\hline Sparisoma axillare & 104 & 3.69 & $1.5-9.0$ & 37.0 & 1.50 & $0.1-11.6$ \\
\hline Sparisoma amplum & 6 & 4.01 & $2.5-5.7$ & 65.0 & 1.65 & $0.7-3.5$ \\
\hline Sparisoma frondosum & 1 & 2.53 & - & 40.0 & 0.21 & - \\
\hline Malacoctenus delalandii & 2 & 4.21 & $3.4-5.0$ & 8.2 & 1.12 & $0.6-1.6$ \\
\hline Barbulifer ceuthoecus & 1 & 2.71 & - & 3.5 & 0.11 & - \\
\hline Ctenogobius saepepallens & 15 & 2.28 & $1.7-3.0$ & 5.0 & 0.15 & $0.1-0.3$ \\
\hline Acanthurus chirurgus & 4 & 4.02 & $2.4-5.2$ & 41.0 & 2.05 & $1.4-2.9$ \\
\hline Stephanolepis hispidus & 1 & 3.72 & - & 38.0 & 0.82 & - \\
\hline Sphoeroides spengleri & 46 & 2.61 & $1.4-8.5$ & 30.0 & 0.88 & $0.1-13.6$ \\
\hline Sphoeroides testudineus & 15 & 7.59 & $1.0-11.0$ & 38.8 & 12.73 & $0.1-33.0$ \\
\hline Sphoeroides greeleyi & 2 & 1.65 & $1.5-1.8$ & 18.0 & 0.31 & $0.1-0.5$ \\
\hline
\end{tabular}

nities. The equipment and methodology used in this study is similar to those used in Schwamborn (2004) and Rezende (2008); however, it was performed manually and only during the winter (rainy season). This maneuver brought some advantages, as the noise of the motorboat engine may drive off individuals and, thus, increase the selectivity of larger size fishes, with more ability to swim. Therefore, the sampling method used in the present study is probably more robust in this respect.
For the seagrass beds of Itamaracá - Pernambuco State, Schwamborn (2004) found that the Shannon-Wiener index $\left(\mathrm{H}^{\prime}=1.43\right)$ and the richness index of Margalef ( $\mathrm{D}=3.00$ to 4.4 ) showed the highest values during the rainy season. The values reported in the present study were higher than those observed by Schwamborn (2004).

Analyzing the ichthyofauna in the same site of this study, Rezende (2008) found the highest values of diversity and equitability in the warmer months (dry sea- 
Trophic guilds (\%) - Species

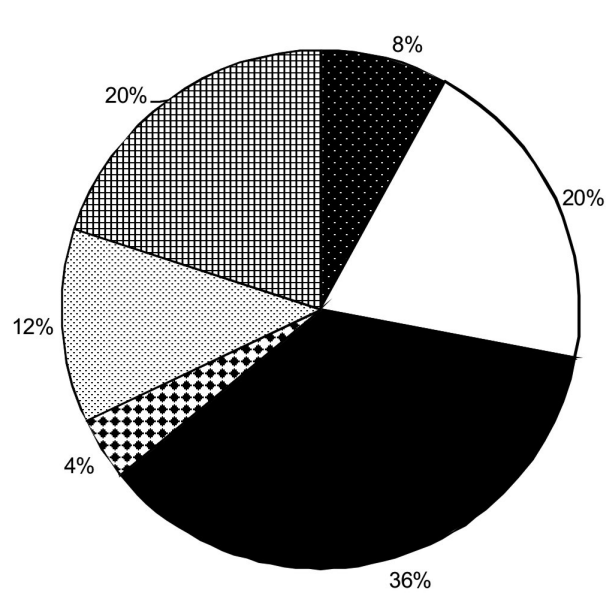

- Omnivores (OMN)

Mobile invertebrate feeders (MIF)

Sessile invertebrate feeders (SIF)
Trophic guilds (\%) - Individuals

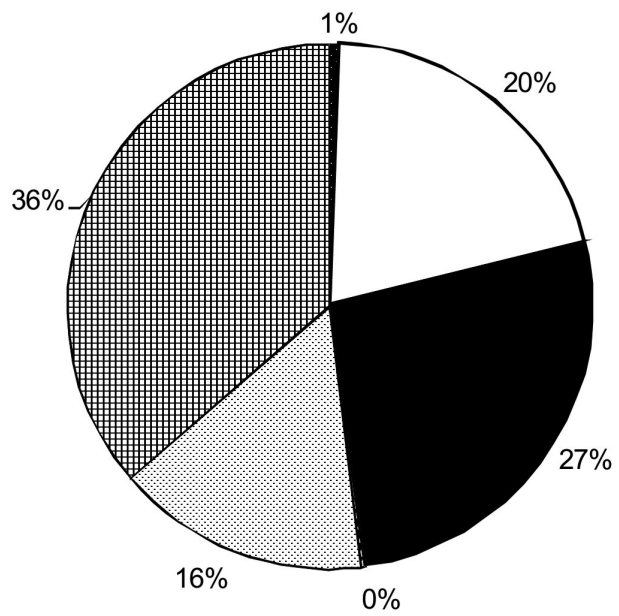

$\square$ Carnivorous (CAR) Piscivores (PIS) 四Herbivores (ROVH)

Fig. 5 - Trophic organization of the collected ichthyofauna for species and individuals during the winter on Carneiros beach, Tamandaré - PE.

son). In June, Rezende (2008) obtained ( $\mathrm{H}^{\prime}=1.52$ and $\left.\mathrm{J}^{\prime}=0.38\right)$, and this study $\left(\mathrm{H}^{\prime}=1.75\right.$ and $\left.\mathrm{J}^{\prime}=0.54\right)$; in July, $\left(\mathrm{H}^{\prime}=1.66\right.$ and $\left.\mathrm{J}^{\prime}=0.41\right)$, and this study $\left(\mathrm{H}^{\prime}=\right.$ 2.23 and $\left.\mathrm{J}^{\prime}=0.69\right)$; and in August, $\left(\mathrm{H}^{\prime}=1.47\right.$ and $\mathrm{J}^{\prime}$ $=0.36)$, and this study $\left(\mathrm{H}^{\prime}=1.73\right.$ and $\left.\mathrm{J}^{\prime}=0.53\right)$. It was noted that the values of diversity were very similar. However in the present study, they were higher, possibly due to the aforementioned methodological problems using motorboat.

Comparing the species composition with a survey of reefs in the region of Tamandaré (Ferreira and Cava 2001), 20 species (80.0\%) were also found in the reef environments. When the same comparison is made with the estuarine ichthyofauna obtained during a study in the same region (F.L.B. Santos, unpublished data), only nine (36.3\%) and (Paiva et al. 2008) ten species (40.0\%) that occurred in the estuary of the Formoso River were collected in the meadow. Therefore, we suggest that the species composition of seagrass beds has a greater influence of reef environments.

The mobile invertebrate feeders trophic guild was the most representative. This fact was also evidenced in several seagrass beds throughout the world (Greenway 1995, Nakamura et al. 2003, Allen et al. 2006, Unsworth et al. 2007). The preference for these environments by the ichthyofauna is due to the large availability of invertebrates (crustaceans, polychaets and molluscs) living in association with the seagrass (Nakamura and Sano 2005, Casares and Creed 2008).

The presence in this seagrass of a large number of herbivores contradicts the theories related to feeding habits of herbivorous and seagrass beds (Bell and Pollard 1989, Allen et al. 2006), where the abundance of herbivores and the consumption of algae by the community is low, despite the availability of the algae forming the meadows. However, another hypothesis, which corroborates the present study, argues that large herbivores use algae as a food resource (Lobel and Ogden 1981, Nakamura et al. 2003), specifically for individuals of the families Scaridae and Acanthuridae (Randall 1965, Ferreira and Gonçalves 2006).

Marine seagrass beds worldwide are suffering a reduction of their areas due to the process of urbanization and human interference on the coast (Duarte 2002, Marques and Creed 2008). In several places, partial or even total degradation is found (Hemminga and Duarte 2000). This fact directly affects the fauna associated with this environment (Hovel and Lipcius 2001). According to the Global monitoring and information network for seagrass meadows - SeagrassNet (Short et al. 
2006), a decline was observed in two populations in the Brazilian coast: one in Paraná State and the other in Abrolhos bank, Bahia State. The analyzed region in this study is within the limits of two marine protected areas, which enhances the need for management strategies of sustainable use and ecosystem conservation. Such strategies should include measures to protect the seagrass beds from a diversity of impacts, including the removal of algae. User restrictions to avoid trampling and tourism by avoiding the presence of vessels, for instance, is urgently needed, since these are important nursery sites for reef fishes. Fishery in reef environments is an activity of great social and economic importance in the region (Ferreira and Maida 2001), whose sustainability depends on the integrity of habitats that are essential to the fish fauna.

\section{ACKNOWLEDGMENTS}

The authors thank Alfredo Carvalho Filho for helping with species identification, Lais Chaves for the English review, João Lucas Feitosa for the map drawing, Centro de Pesquisa e Gestão de Recursos Pesqueiros do Nordeste (CEPENE/ICMBio) for the use of laboratories, and IBAMA for the license no. 16109-1. They also thank the team of Projeto Meros do Brasil (Alberto, Manuel and Nino), who helped in the fieldwork.

\section{RESUMO}

Pradarias de fanerógamas são utilizadas pela ictiofauna, de maneira geral como ambiente de berçário, abrigo contra predadores, diminuição de competição e maior disponibilidade de recursos alimentares, estabelecendo uma relação de conectividade com demais ecossistemas costeiros. No presente estudo foi avaliada a estrutura da ictiofauna associada às pradarias de fanerógamas do estuário do Rio Formoso no litoral de Pernambuco durante o inverno de 2008. Foram realizados no total 27 arrastos manuais (15 diurnos e 12 noturnos), nos quais foram amostrados 358 peixes pertencentes a 18 famílias, 21 gêneros e 25 espécies. A Captura por unidade de esforço (CPUE) média por arrasto foi de 13,5 indivíduos e 4,95 espécies por arrasto. As famílias mais abundantes foram Scaridae $(n=111)$, Tetraodontidae $(\mathrm{n}=63)$, Lutjanidae $(\mathrm{n}=56)$, Mullidae $(\mathrm{n}=$ 39) e Engraulidae $(n=19)$. Analisando os índices ecológicos, observou-se que os mesmos foram sempre maiores para o período da noite, confirmando o fato do uso de tais áreas pela ictiofauna de forma mais intensa neste período. A necessidade de medidas para proteção destas áreas é evidente na região devido a sua importância e vulnerabilidade a impactos antrópicos.

Palavras-chave: conectividade, bancos de fanerógamas, peixes recifais, diversidade.

\section{REFERENCES}

AdAms AJ AND EBERSOLE JP. 2002. Use of back-reef lagoon habitats by coral reef fishes. Mar Ecol Prog Ser 228: 213-226.

Allen T, JimÉnez M AND VillafranCA S. 2006. Estructura y categorías tróficas de peces asociados a praderas de Thalassia testudinum (Hydrocharitales, Hydrocharitaceae) en el golfo de Cariaco, Estado de Sucre, Venezuela. Invest Mar 34(2): 125-136.

Allen T, Jiménez M, Marquez B And Figueroa Y. 2007. Ictiofauna de tres praderas de Thalassia testudinum de la costa norte del Golfo de Santa Fé, Estado Sucre, Venezuela. Bol Inst Oceanogr Venezuela 46: 67-78.

Alves MS. 2000. Fauna associada aos prados de Halodule wrightii Aschers. In: BARros HM, EsKINAZI-LEÇA E, Macedo SJ AND Lima T (Eds), Gerenciamento participativo de Estuários e Manguezais. Ed. Universitária da UFPE, Recife, p. 75-97.

Ayres M, Ayres MJR, Ayres DL and Santos AAS. 2003. BioEstat 3.0: aplicações estatísticas nas áreas de Ciências Biológicas e Médicas. Belém, Sociedade Civil Mamirauá, 290 p.

BAELDE P. 1990. Differences in the structures of fish assemblages in Thalassia testudinum beds in Guadalupe, French West Indies, and their ecological significance. Mar Biol 105: 163-173.

Barletta M, Barletta-Bergan A, Saint-Paul U AND HuBOLD G. 2005. The role of salinity in structuring the fish assemblages in a tropical estuary. J Fish Biol 66: $45-72$.

BECK MW ET AL. 2001. The identification, conservation, and management of estuarine and marine nurseries for fish and invertebrates. Bioscience 51: 633-642.

BELl JD AND HARMELIN-VIVIEN ML. 1982. Fish fauna of French Mediterranean Posidonia oceanica seagrass meadows. 1. Community structure. Tethys 10: 337-347.

BELl JD AND POLlard DA. 1989. Ecology of fish assemblages and fisheries associated with seagrass. In: LARKUM AWD, MCCOMB AJ AND SHEPARD AS (Eds), Biology of Seagrass. Elsevier, Amsterdam, 841 p. 
BLABER SJM AND BLABER TG. 1980. Factors affecting the distribution of juvenile estuarine and inshore fish. J Fish Biol 17: 143-162.

CAsares FA And Creed JC. 2008. Do small A. J . seagrasses enhance density, richness and diversity of macrofauna? J Coastal Research 24(3): 790-797.

Cocheret de la Morinière E, Pollux BJA, NagelKERKEN I AND VAN DER VELDE G. 2003. Diet shifts of Caribbean grunts (Haemulidae) and snappers (Lutjanidae) and the relation with nursery-to-coral reef migrations. Est Coast Shelf Sci 57: 1079-1089.

DUARTE CM. 2002. The future of seagrass meadows. Environ Conser 29(2): 192-206

FERREIRA BP AND CAVA F. 2001. Ictiofauna marinha da APA Costa dos Corais: lista de espécies através de levantamento da Pesca e Observações Subaquáticas. Bol Tec Cient CEPENE 9: 167-180.

Ferreira BP AND Maida M. 2001. Fishing and the Future of Brazil's Northeastern Reefs. InterCoast 38: 22-23.

FERREIRA CEL AND GonÇALVES JEA. 2006. Community structure and diet of roving herbivorous reef fishes in the Abrolhos Archipelago, south-western Atlantic. J Fish Biol 69(4): 1533-1551.

Ferreira Cel, Floeter SR, Gasparini JL, Joyeux JC AND FERREIRA BP. 2004. Trophic structure patterns of Brazilian reef fishes: a latitudinal comparison. J Biogeogr 31: 1093-1106.

FISHBASE 2009. Species catalog. World Wide Web: $<$ http://www.fishbase.org.html>.

GREENWAY M. 1995 Trophic relationships of macrofauna within a Jamaican seagrass meadow and the role of the echinoid Lytechinus variegatus (Lamarck). Bull Mar Sci 56(3): 719-736.

Gillanders BM, Able KW, Brown JA, Eggleston DB AND SHERIDAN PF. 2003. Evidence of connectivity between juvenile and adult habitats for mobile marine fauna: an important component of nurseries. Mar Ecol Prog Ser 247: 281-295.

Hemminga MA And DuARTe CM. 2000. Seagrass Ecology. Cambridge University Press, UK.

Hovel KA AND LiPciUs RN. 2001. Habitat fragmentation in a seagrass landscape: patch size and complexity control blue crab survival. Ecol 82: 1814-1829.

Humann P And Deloach N. 2002. Reef fish identification: Florida, Caribbean and Bahamas. New World Publications, Florida, 481 p.
Jelbart JE, Pauline MR And Rod MC. 2007. Patterns of small fish distributions in seagrass beds. J Mar Biol Assoc 87: 1297-1307.

JERNAKOFF P, BREARLEY A AND NiELSEN J. 1996. Factors affecting grazer-epiphyte interactions in temperate seagrass meadows. Oceanogr Mar Biol 34: 109-162.

KWAK SN AND KLUMPP DW. 2004. Temporal variation in species composition and abundance of fish and decapods in Cockle Bay, North Queensland, Australia. Aquat Bot 78: 119-134.

LAEGDSGAARD P AND JoHnSON C. 1995. Mangrove habitats as nurseries: unique assemblages of juvenile fish in subtropical mangroves in eastern Australia. Mar Ecol Prog Ser 126: 67-81.

LAEGDSGAard P AND Johnson C. 2001. Why do juvenile fish utilize mangrove habitats? Exp Marine Biol Ecol 257: 229-253.

LAROche J, BARAN E AND RASOANANDRASANA NB. 1997. Temporal patterns of fish assemblage in a semi-arid mangrove zone in Madagascar. J Fish Biol 51: 3-20.

Letourneur Y, Darnaude A, SALEn-PicArd C AND HARMELIN-VIVIEN MM. 2001. Spatial and temporal variations of fish assemblages in a shallow Mediterranean soft-bottom area (Gulf of Fos, France). Oceanol Acta 24: 273-285.

Lindeman KC, Pugliose R, Waugh GT and Ault JS. 2000. Developmental patterns within a multispecies reef fishery: management applications for essential fish habitats and protected areas. Bull Mar Sci 66: 929-956.

LOBEL PS AND OGDEN JC. 1981. Foraging by the herbivorous parrotfish Sparisoma radians. Mar Biol 54: 173-183.

Lugendo BR, NAgelkerken I, Jiddawi N, Mgaya YD AND VAN DER VELDE G. 2007. Fish community composition of a tropical nonestuarine embayment in Zanzibar, Tanzânia. Fish Sci 73: 1213-1223.

MAIDA M AND FERREIRA BP. 1997. Coral Reefs of Brazil: an overview. Proceedings of the $8^{\text {th }}$ International Coral Reef Symposium 1: 263-273.

Marques LV AND CREed JE. 2008. Biologia e ecologia das fanerógamas marinhas do Brasil. Oecol Bras 12(2): 315-331.

Meyer J, Schultz ET And Helfman GS. 1983. Fish schools: an asset to corals. Science 200: 1047-1049.

Mumby PJ ET AL. 2003. Mangroves enhance the biomass of coral reef fish communities in the Caribbean. Nature 427: 533-536. 
NAGelkerken I, VAN DER Velde G, Gorissen MW, Meijer GJ, VAn'T Hof T AND Den Hartog C. 2000. Importance of mangroves, seagrass beds and the shallow coral reef as a nursery for important coral reef fishes, using a visual census technique. Est Coast Shelf Sci 51: 31-44.

NAKAMURA Y AND SANO M. 2005. Comparison of invertebrate abundance in a Seagrass bed and adjacent Coral and sand areas at Amitori Bay, Iriomote Island, Japan. Fish Sci 71: 543-550.

NAKAmura Y AND TsuchiYA M. 2008. Spatial and temporal patterns of seagrass habitat use by fishes at the Ryukyu Islands, Japan. Est Coast Shelf Sci 76: 345-356.

NAKAMURA Y, HorinouChI M, NAKAI T AND SANO M. 2003. Food habits of fishes in a seagrass bed on a fringing coral reef at Iriomote Island, southern Japan. Ichthyol Research 50: 15-22.

NELSON JS. 2006. Fishes of the world. New York, J Wiley $\&$ Sons, $4^{\text {th }}$ ed., $601 \mathrm{p}$.

Paiva ACG, Chaves PTC AND AraúJo ME. 2008. Estrutura e organização trófica da ictiofauna de águas rasas em um estuário tropical. Rev Bras Zool 25(4): 647-661.

PARRISH JD. 1989. Fish communities of interacting shallowwater habitats in tropical oceanic regions. Mar Ecol Prog Ser 58: 143-160.

POLlaRd DA. 1984. A review of ecological studies on seagrass-fish communities, with particular reference to recent studies in Australia. Aqua Bot 18: 3-42.

QUinN NJ. 1980. Analysis of temporal changes in fish assemblages of Serpentine Creek, Queensland, Australia. Environ Biol Fish 5: 117-133.

RAmos MA. 1973. Lista preliminar dos crustáceos decápodes natantes dos prados de Halodule de Pernambuco e Paraíba. In: REUnião ANuAl dA SocIEdAde BRASILEIRA PARA O PROGRESSO DA CIÊNCIA, 25. Guanabara. Resumos, São Paulo, SBPC, 351 p.

RANDALL JE. 1965. Grazind effect on sea grasses by herbivorous reef fishes in the West Indies. Ecol 46(3): 255-260.
REZENDE SM. 2008. Tendências temporais das capturas, determinação da idade, crescimento e recrutamento de espécies de peixes Lutjanidae que ocorrem na costa nordeste do Brasil. Tese de Doutorado, Depto Oceanografia Centro de Tecnologia e Geociências, Universidade Federal de Pernambuco, UFPE, 186 p.

Roth J, Haycoock K, Gagnon J, Soper C AND CALDAROLA J. 1995. StatView software. Abacus Inc. Barkley, Califórnia.

SCHWAMBORN SHL. 2004. Dinâmica e organização trófica de assembleias de peixes associados aos prados de capim marinho (Halodule wrightii) de Itamaracá, Pernambuco. Tese de doutorado, Universidade Federal de Pernambuco, Centro de Tecnologia e Geociências, Departamento de Oceanografia, Recife, 315 p.

Short FT, Koch EW, Creed JC, Magalhães KM, FerNANDEZ E AND GAECKLE JL. 2006. SeagrassNet monitoring across the Americas: case studies of seagrass decline. Mar Ecol 27: 277-289.

Unsworth RKF, Wylie E, SMith DJ AND Bell JJ. 2007. Diel trophic structuring of seagrass bed fish assemblages in the Wakatobi Marine National Park, Indonesia. Est Coast Shelf Sci 72: 81-88.

Verweij MC, Nagelkerken I, Wartenbergh SLJ, PEN IDO R AND VAN DER VELde G. 2006. Caribbean mangroves and seagrass beds as daytime feeding habitats for juvenile French grunts, Haemulon flavolineatum. Mar Biol 149: 1291-1299.

WEINSTEIN MP AND HECK K. 1979. Ichthyofauna of seagrass meadows along the Caribean coast of Panama and in the Gulf of Mexico: Composition, structure and community ecology. Mar Biol 50: 97-108.

ZAR JH. 1999. Biostatistical analysis. New Jersey, PrenticeHall, 663 p. 